\title{
KEMISKINAN DALAM PERSPEKTIF STRUKTURAL FUNGSIONAL
}

\author{
Ellya Rosana \\ Universitas Islam Negeri Raden Intan Lampung \\ ellyarosana@radenintan.ac.id
}

\begin{abstract}
Poverty is a person's inability to meet their needs caused by the scarcity of tools to meet daily needs, education, and inadequate employment to meet the needs of life. Efforts are being made to reduce poverty increasingly diverse but poverty is indeed difficult to be eliminated, but at least it can be minimized. Adherents of functional structural theory assume that poverty is functional (has a function) on social systems in society. The poor function to do "dirty work." that is not possible for the rich. In this case, it does not mean that poverty must be maintained, but when the function of poverty can be replaced by other sub-systems, poverty may disappear from the community's sub-system.
\end{abstract}

\section{Abstrak}

Kemiskinan merupakan ketidaksanggupan seseorang dalam memenubi kebutubannya yang disebabkan oleh kelangkaan alat pemenuban kebutuban sehari-hari, pendidikan, dan pekerjaan yang tidak mencukupi untuk memenubi kebutuban bidup. Upaya yang dilakukan untuk mengentaskan kemiskinan semakin beragam tetapi kemiskinan memang sulit untuk dibilangkan, tetapi setidaknya dapat diminimalisir. Penganut teori struktural fungsional mengangsap bahwa kemiskinan adalah fungsional (mempunyai fungsi) terbadap sistem sosial dalam masyarakat. Masyarakat miskin berfungsi untuk. mengerjakan "pekerjaan kotor" yang tidak mungkin dikerjakan oleh orang kaya. Dalam hal ini bukan berarti kemiskinan harus dipertabankan, tetapi ketika fungsi kemiskinan itu sudah bisa digantikan oleh sub sistem yang lain, bisa saja kemiskinan itu bilang dari sub sistem masyarakat.

Keywords: Poverty, Functional Structural 


\section{A. Pendahuluan}

Kemiskinan merupakan masalah sosial yang selalu ada dan sampai saat ini sulit untuk dipecahkan. Kemiskinan secara ekspisit merupakan suatu gejala sosial, yaitu bagaimana usaha yang dilakukan oleh masyarakat dalam mencukupi kebutuhan hidupnya, dan bagaimana usaha tersebut dapat mencapai apa yang diharapkan. Jika pemikiran tersebut yang berkembang maka program penanggualangan kemiskinan tidak akan mampu memecahkan masalah yang sebenarnya, sebab program tersebut hanya diarahkan hanya untuk memenuhi kebutuhan, dan bukan membantu dalam memecahkan masalah itu sendiri.

Akibat yang ditimbulkan dari kemiskinan bukan hanya masyarakatnya menjadi sengsara, tetapi dapat membuat kehidupan masyarakat menjadi semakin sulit karena dapat mengakibatkan pengangguran, kelaparan, kebodohan, dan sebagainya yang merupakan dampak lain dari kemiskinan itu.

Orang yang hidup dalam kemiskinan pun akan sulit mengakses berbagai sumber daya yang nantinya bisa digunakan untuk keluar dari kemiskinan, seperti ilmu pengetahuan dan teknologi, yang hanya bisa diperoleh apabila seseorang itu sudah bisa keluar dari garis kemiskinan. Hal tersebut terjadi karena untuk mengakses ilmu pengetahuan dan teknologi tersebut diperlukan modal yang tidak sedikit yang tidak mungkin dimiliki oleh orang miskin.

Modal yang sangat kurang itu akan menyulitkan bagi orang miskin untuk melakukan aktivitas yang dapat mengeluarkan mereka dari jurang kemiskinan, karena jangankan untuk melakukan saving atau menabung, untuk memenuhi kebutuhan sehari-hari saja sulit. Biasanya orang miskin bekerja pada sektor yang rendahan sehingga keuntungan yang diperoleh pun sangat sedikit yang mengakibatkan mereka mengalami kesulitan untuk meningkatkan perekonomiannya.

Pemberdayaan masyarakat diharapkan mampu untuk menanggulangi kemiskinan yang dilakukan dengan cara peningkatan kualitas sumber daya manusia yang nantinya secara tidak langsung dapat menopang perekonomian, jika pemberdayaan kualitas sumber daya manusia dan sumber daya sosial dapat berjalan sesuai dengan harapan. 
Kemiskinan dikategorikan sebagai masalah sosial dimulai pada saat perdagangan berkembang dengan pesat dan timbulnya nilai-nilai sosial baru, yang sebelumnya keadaan kaya dan miskin dapat hidup secara berdampingan. Terjadinya perbedaan kedudukan dalam masyarakat lah yang sebenarnya merupakan masalah sosial terutama di bidang ekonomi, yang merupakan ukuran dari kemiskinan itu . ${ }^{1}$

Kadang-kadang masyarakat tidak sadar bahwa dirinya masuk kategori miskin, karena yang dilihat dan dirasakannya sejak awal sudah demikian adanya. Mereka baru menyadari setelah membandingkan kehidupannya dengan orang lain.

\section{B. Pengertian Kemiskinan}

Kemiskinan sering dimaknai sebagai ketidakmampuan untuk memenuhi kebutuhan dasar, seperti pangan, pakaian, papan, pendidikan, dan kesehatan. Kemiskinan terjadi karena kesulitan dan kelangkaan alat pemenuhan kebutuhan dasar, ditambah dengan sulitnya mendapatkan pekerjaan yang layak dengan penghasilan yang mampu memenuhi kebutuhan hidupnya. ${ }^{2}$

Orang dikatakan miskin jika kehidupannya dibandingkan dengan kehidupan orang lain lebih rendah sesuai dengan standar yang sudah ditentukan atau berlaku dalam masyarakat. Ketika seseorang kekurangan sumber daya untuk memenuhi kebutuhan hidupnya, maka dapat dikatakan bahwa seseorang itu miskin secara ekonomi, dan juga bisa digambarkan dengan produktivitas yang rendah, pendapatan/penghasilan yang rendah, hasil poroduksi orang miskin yang juga lemah dalam nilai tukarnya, dan kesempatan ikut serta dalam pembangunan pun sangat terbatas. ${ }^{3}$

Ada pula yang mengartikan kemiskinan itu terjadi karena anggota masyarakat baik itu seseorang maupun keluarga tidak dapat

1 Soerjono Soekanto, Sosiologi Suatu Pengantar, Jakarta : Raja Grafindo Persada, 1994), h. 406-407

2 Gunawan Sumodiningrat dan Ari Wulandari, Membangun Indonesia dari Desa Pemberdayaan Desa sebagai Kunci Kesuksesan Pembangunan Ekonomi untuk meningkatkan Kesejabteraan Rakyat (Yogyakarta : Media Pressindo, 2016), h. 61

3 Zaini Rohmad, Sosiologi Pembangunan, (Yogyakarta : Ombak Tiga, 2016), h. $269-270$ 
memenuhi kebutuhan hidupnya secara wajar sebagaimana orang lain dengan standar yang sudah ditetapkan. Ketika terjadi pergeseran terhadap ukuran dari kemiskinan itu yang kemudian menjadi suatu kesepakatan atau kelaziman pada masyarakat tertentu, maka ukuran dari kemiskinan pun akan berubah sesuai dengan pertumbuhan dan perkembangan masyarakat. ${ }^{4}$

Pengertian kemiskinan dalam perspektif ilmu-ilmu sosial sebagaimana yang dikemukakan oleh Parsudi Suparlan bahwa kemiskinan diartikan sebagai kekurangan materi secara standar yang terjadi pada seseorang atau sekelompok orang jika dibandingkan dengan orang lain yang akan mempengaruhi tingkat kesehatan, kehidupan moral, dan rasa harga diri dari mereka yang tergolong orang miskin. ${ }^{5}$

Kaya dan miskin dapat diukur dari kemampuan seseorang atau sekelompok orang dalam kepemilikan nilai-nilai ekonominya. Masalah sosial yang dalam hal ini adalah kemiskinan akan nuncul jika terjadi kepincangan terhadap nilai-nilai ekonomi yang mengakibtkan masyarakat tidak dapat memenuhi kebutuhan pokoknya. ${ }^{6}$

Kemiskinan terjadi karena kesulitan dan kelangkaan alat pemenuhan kebutuhan dasar, ditambah dengan sulitnya mendapatkan pekerjaan yang layak dengan penghasilan yang mampu memenuhi kebutuhan hidupnya. Kemiskinan bisa diibaratkan sebagai lingkaran tanpa ujung. Jika seseorang sudah masuk dalam lingkaran kemiskina tersebut, maka akan sulit baginya untuk keluar dari garis kemiskinan karena biasanya orang miskin hanya dapat memenuhi kebutuhan pokoknya saja, dan itu pun sangat sulit. Mereka kesulitan untuk keluar dari kemiskinan karena salah satu cara untuk keluar dari lingkaran kemiskinan adalah dengan pendidikan/sekolah, tetapi masalah yang dihadapi orang miskin adalah kesulitan untuk mengenyam pendidikan karena biaya yang relatif mahal yang biasanya tidak terjangkau oleh masyarakat miskin. Akibatnya kemiskina tersebut diwariskan kepada anak cucunya yang tidak mungkin bisa keluar dari lingkaran kemiskinan. 1994), h. 190

${ }^{4}$ Abdulsyani, Sosiologi Skematika, Teori dan Terapan, Jakarta : Bumi Aksara,

5 Parsudi Suparlan, Kemiskinan di Perkotaan, (Jakarta : Yayasan Obor Indonesia, 1995), h. xi

${ }^{6}$ Ibid, h. 191 
Menurut Soerjono Soekanto kemiskinan diartikan sebagai suatu keadaan dimana seseorang tidak sanggup memelihara dirinya sendiri sesuai dengan taraf kehidupan kelompok dan juga tidak mampu memanfaatkan tenaga mental maupun fisiknya dalam kelompok tersebut. ${ }^{7}$

Konsep kemiskinan oleh Effendi dibedakan menjadi tiga dimensi yaitu dimensi ekonomi, sosial, dan politik. Kekurangan sumber daya dapat dikategorikan sebagai dimensi ekonomi yang diharapkan nantinya dapat meningkatkan kesejahteaan hidup apabila ekonomi dapat ditingkatkan. Konsep kemiskinan secara sosial dapat diartikan sebagai kurangnya masyarakat untuk mendapatkan kesempatan-kesempatan untuk meningkatkan produktivitas mereka ataupun hambatan-hambatan yang timbul pada masyarakat untuk memanfaatkan kesempatan-kesempatan yang ada. Sedangkans secara politik, kemiskinan daopat diartikan sebagai ketidakmampuan seseorang dalam menentukan pilaihannya sendiri yang memiliki kaitan dengan kepemilikan umum, misalnya tidak dilibatkan dalam pengambilan suatu keputusan dalam penentuan program. $^{8}$ Jadi miskin disini bukan hanya tidak dapat memenuhi kebutuhan seharihari saja (ekonomi), tetapi dalam aspek yang lebih luas mengenai kehidupan manusia secara keseluruhan.

Kemiskinan merupakan suatu fenomena persoalan struktural dan multidimensional yang mencakup politik, sosial, ekonomi, aset, dan lain-lain. Bentuk-bentuk dimensi kemiskinan dalam kehidupan sehari-hari adalah sebagai berikut: ${ }^{9}$

1. Orang miskin biasanya tidak mempunyai wadah untuk menyalurkan aspirasinya dalam bidang politik, padahal pengambilan keputusan menyangkut kepentingan mereka, hal ini adalah wujud dari dimensi politik.

2. Tidak bisa masuk atau ikut sertanya masyarakat miskin ke dalam lembaga sosial yang ada di masyarakat dan sudah mendarah dagingnya budaya kemiskinan yang dapat

\footnotetext{
${ }^{7}$ Soerjono Soekanto, Sosiologi Suatu ........, h 406

8 Noer Tadjuddin Effendi, Sumber Daya Manusia, Peluang Kerja, dan Kemiskinan (Yogyakarta : Tiara Wacana, 1995)

9 Adon Nasrullah Jamaludin, Sosiologi Perkotaan Memahami Masyarakat Kota dan Problematikanya, (Bandung: Pustaka Setia, 2015) h. 232
} 
mempengaruhi kualitas manusia dan semangat keja orang miskin tersebut, sebagai wujud dari dimensi sosial.

3. Masyarakat cenderung tidak bisa menjaga lingkungan, dengan sikapnya yang masih kurang mendukung proses pembangunan yaitu masih adanya perilaku yang mengarah pada kegiatan yang tidak mendukung dalam memelihara dan melindungi daerah sekitar dan lingkungannya, yang merupakan wujud dimensi lingkungan

4. Penghasilan orang miskin yang rendah yang menyebabkan mereka tidak dapat memenuhi kebutuhan hidupnya secara wajar, yang merupakan wujud dari dimensi ekonomi

5. Kurang memadainya pendapatan masyarakat miskin, merupakan wujud dari dimensi aset

Menurut Ali Yafie sebagaimana dikutip oleh Wildana Wargadinata, ${ }^{10}$ kemiskinan dan kemelaratan bisa ditimbulkan oleh hal-hal sebagai berikut: Pertama, Kelemahan, apakah itu kelemahan hati atau semangat, atau kelemahan akal dan ilmu, ataukah kelemahan fisik. Hal tersebut dapat mengurangi pilihan dan keinginan manusia yang tidak bisa melaksanakan tugasnya dan memenuhi kebutuhan hidupnya secara wajar.

Kedua, malas; orang yang malas sangat sulit untuk keluar dari kemiskinan, karena dari dalam dirinya sendiri tidak ada usaha untuk keluar dari kemiskinan. Ketiga, ketakutan; orang takut dalam berusaha terutanma takut gagal akan sulit keluar dari kemiskinan, karena dia tidak berani berusaha dan mencoba karena selalu dihantui ketakutan akan kegagalan. Keempat, pelit; seseorang yang pelit akan menghambat orang lain untuk meningkatkan taraf kehidupannya, karena tidak memberi bantuan kepada orang miskin untuk memenuhi kebutuhan hidupnya yang nantinya diharapkan akan membantu keluar dari kemiskinan. Kelima, terlilit hutang; orang yang dalam hidupnya selalu mengandalkan hutang, akan sulit baginya untuk keluar dari kemiskinan. Dalam ajaran Islam pun kita harus berhatihati agar jangan terjerat hutang, karena akibatnya bukan hanya di dunia tetapi juga di akhirat kelak. Bahkan Islam pun mewajibkan

${ }^{10}$ Wildana Wargadinata, Islam dan Pengentasan Kemiskinan, (Malang : UIN Maliki Press, 2011), h. 18 
bagi orang yang meninggal dunia wajib membayar hutangnya yang deilakukan oleh ahli warisnya. Keenam, diperas atau dikuasai sesama manusia.

Sememtara itu, Robert Chambers menegaskan bahwa faktor penyebab terjadinya kemiskinan adalah : lilitan kemiskinan, hilangnya hak atau kekayaan yang sukar untuk kembali, mungkin disebabkan desakan kebutuhan yang melampaui ambang batas kekuatannya, misalnya pengeluaran yang sudah diperhitungkan sebelumnya, namun jumlahnya sangat besar, atau tiba-tiba dihadapkan pada krisis yang hebat. Lazimnya kebutuhan yang mendorong seseorang yang terlilit kemiskinan, berkaitan dengan lima hal; kewajiban adat, musibah, ketidakmampuan fisik, pengeluaran tidak produktif, dan pemerasan. ${ }^{11}$

Merujuk pada pemikiran Friedmann, kemiskinan digambarkan sebagai ketidaksamaan kesempatan untuk mengakumulasikan basis kekuatan sosial yang meliputi : 1) modal sosial, antara lain lahan, tempat tinggal, perlengkapan, kesehatan, dan sebagainya; 2) Sumber-sumber keuangan, seperti income dan kredit yang memadai; 3) Organisasi sosial dan politikyang dapat digunakan untuk mencapai kepentingan bersama, misalnya partai politik; 4) Jaringan sosial untuk memperoleh pekerjaan, barang, dan lainnya; 5) Pengetahuan dan keterampilan yang memadai; 6) Informasi yang berguna untuk memajukan kehidupan mereka. ${ }^{12}$

Dari segi sosial, kemiskinan penduduk dapat juga digambarkan sebagai suatu kondisi sosial yang sangat rendah, seperti tidak/kurang tersedianya fasilitas kesehatan, masih banyak masyarkat miskin yang belum mempunyai kesempatan untuk bersekolah. Dari segi ekonomi, keluarga miskin ditandai dengan sebagian besar masyarakatnya baik di desa maupun di kota bermata pencaharian pada sektor informal, pekerjaan masyarakatnya tidak menetap, karena mereka ingin memperoleh penghasilan yangn lebih baik lagi. Selain itu keluarga miskin juga dalam memenuhi kebuutuhan hidupnya dari sebagian anggaran rumahnya. ${ }^{13}$

${ }^{11}$ Zaini Rohmad, Sosiologi Pembangunan..., h. 278

12 Roestanto Wahidi D, Membangun Perdesaan Moderen Tata Kelola Infrastruktur Desa (Bogor : Indodata Development Center, 2015), h. 11

${ }^{13}$ Ibid. 
Lebih lanjut, Adon Nasrullah mengemukakan indikator utama kemiskinan adalah $:^{14}$

1. Makanan, pakaian, dan tempat tinggal yang tidak layak atau masih kurang

2. Terbatasnya kepemilikan tanah dan alat-lat produktif

3. Seseorang atau sekelompok orang (masyarakat) masih banyak yang buta huruf

4. Kesejahteraan hidup masyarakat yang maih kurang

5. Kerentanan dan keterpurukan dalam bidang sosial dan ekonomi

6. Ketidakberdayaan atau daya tawar yang rendah

7. Terbatasnya kesempatan untuk sekolah

8. Masih kekurangan pangan serta kualitas pangan yang buruk

9. Pelayanan kesehatan dan pendidikan masih sangat rendah, dan kurangnya kesempatan kerja

10. Terbatasnya layanan perumahan dan sanitasi, serta air bersih, dan lain-lain

\section{Macam-macam Kemiskinan}

1. Kemiskinan Absolut

Jika seseorang atau anggota keluarga mempunyai penghasilan yang tidak bisa digunakan untuk memenuhi kebutuhan pangan, sandang dan papan. Konsep ini dimaksudkan untuk menetukan tingkat pendapatan minimum yang cukup untuk memenuhi kebutuhan fisik terhadap makanan, pakaian, dan perumahan untuk menjamin kelangsungan hidup. ${ }^{15}$ Atau dengan kata lain bahwa kemiskinan absolut adalah jika

\footnotetext{
${ }^{14}$ Adon Nasrullah Jamaludin, Sosiologi Perkotaan ..., h. 243

15 Zaini Rohmad, Sosiologi .... h, 283
} 
seseorang tidak dapat memenuhi kebutuhan pokoknya secara minimal. ${ }^{16}$

2. Kemiskinan relatif; adalah suatu kemiskinaan yang disebabkan karena tidakmerataan dalam pendistribusian pendapatan pada masyarakat sebagai akibat dari kebijakan pembangunan yang tidak dapat terjangkau oleh seluruh lapisan masyarakat. Pengertian lain mengatakan bahwa kemiskinan relatif adalah perhitungan kemiskinan berdasarkan proporsi distribusi pendapatan dalam suatu daerah. Dikatakan relatif karena lebih berkaitan dengan distribusi pendapatan antarlapisan sosial masyrakat. ${ }^{17}$

3. Kemiskinan natural; merupakan kemisikinan yang diwariskan dari generasi sebelumnya ke generasi yang akan datang, karena keterbatasan sumber daya yang menjadi penyebab masyarakat sulit untuk berubah. ${ }^{18}$

4. Kemiskinan kultural (Budaya); merupakan kemiskinan yang disebabkan karena masyarkat masih mempertahankan budayanya, yang sebenarnya merupakan sumber dari kemiskinan itu sendiri, yang kadang-kadang masyarakat tidak menyadarinya. ${ }^{19}$

5. Klasifikasi kemiskinan dapat pula dilihat dari pola waktu, seseorang atau keluarga dapat menjadi miskin, yaitu kemiskinan yang telah kronis atau turun temurun (persistent Poverty), kemiskinan yang mengikuti pola siklus ekonomi secara keseluruhan (cyclical poverty), kemiskinan musiman seperti yang dijhumpai pada kasus-kasus nelayan dan petani tanaman pangan, kemiskinan yang disebabkan oleh adanya bencana alam, atau dampak dari suatu kebijakan tertentu yang menyebabkan turunnya tingkat kesejahteraan. ${ }^{20}$

16 Ambar Teguh Sulistiyani, Kemitraan dan Model-model Pemberdayaan (Yogyakarta : Gava Media, 2004), h. 29

17 Zaini Rohmad, Sosiologi .... h, 287

${ }^{18}$ Ambar Teguh Sulistiyani, Kemitraan dan ..., h. 29

19 Ibid.

${ }^{20}$ Gunawan Sumadiningrat, Kemiskinan,....., h.3 


\section{Kemiskinan dalam Pandangan Struktural Fungsional}

Pandangan struktural fungsional menganggap bahwa masyarakat merupakan suatu sistem yang terdiri dari bagian yang saling berkaitan, jika salah satu bagian mengalami kerusakan atau tidak berfungsi sebagaimana mestinya, maka akan mempengaruhi struktur secara keseluruhan. ${ }^{21}$ Konsep-konsep utamanya adalah fungsi, disfungsi, fungsi laten, fungsi manifest, dan keseimbangan

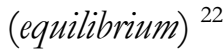

Secara esensial, prinsip-prinsip pokok teori struktural fungsional adalah :

1. Masyarakat terdiri dari satu kesatuan yang terdiri dari elemenelemen yang saling berkaitan dan saling ketergantungan dan setiap elemen akan mempengaruhi elemen yang lain.

2. Setiap elemen dalam dalam suatu masyarakat akan tetap berjalan karena elemen itu mempunyai peran penting dalam memelihara keberadaan dan keadaan masyarakat

3. Semua masyarakat memiliki mekanisme untuk mengintegrasikan dirinya dalam suatu komitmen mengenain kepercayaan dan nilai yang sama

4. Masyarakat cenderung mengarah pada suatu keseimbngan

5. Perubahan sosial merupakan kejadian yang tidak biasa dalam masyarakat, tetapi bila terjadi juga akan membawa keuntungan bagi masyarakat. ${ }^{23}$

Menurut teori ini, masyarakat merupakan suatu sistem sosial yang terdiri atas elemen atau bagian yang saling berkaitan dan

${ }^{21}$ Bernard Raho, Teori Sosiologi Moderen (Jakarta : Prestasi Pustaka, 2007), h.

22 Fungsi disebut nyata (manifest), apabila konsekuensi tersebut disenganja, dimaksudkan atau setidak-tidaknya diketahui. Fungsi disebut sembunyi (latent) apabila konsekuensinya secara objektif ada tetapi tidak (belum) diketahui, dan pembedaan ini banyak memberi manfaat dalam menelaah kesatuan sosial, seperti : dapat membantu orang untuk memahami apa sebabnya praktik-praktik tertentu dalam masyarakat tidak masuk akal dan tidak mencapai tujuannya, masih tetap diteruskan, juga kenyataan sosial dan keadaan yang sebenarnya akan dikenal dengan lebih baik, bila fungsi tersembunyi dari suatu fenomena sosial dipelajari.

${ }^{23}$ Stephen K. Sanderson, Sosiologi Makro (Jakarta : Rajawali Press, 1993), h. 
menyatu dalam keseimbangan. Perubahan yang terjadi pada salah satu bagian akan membawa perubahan pula bagian yang lain. Asumsi dasarnya adalah bahwa setiap struktur dalam sistem sosial, fungsional terhadap yang lain. Jika tidak fungsional maka struktur itu tidak akan ada atau hilang dengan sendirinya. ${ }^{24}$

Beberapa asumsi dasar teori struktural fungsional menurut Craib, Pertama, norma dan nilai-nilai adalah unsur dasar dari kehidupan sosial. Bagi penganut teori ini norma dan nilai dibangun secara kolektif dan bukan dikonstruksikan oleh kelompok tertentu. Kedua, kehidupan sosial melibatkan komitmen diantara anggotaanggotanya bukan melibatkan dorongan yang mengarah pada perlawanan. Ketiga, kelompok, komunitas, dan masyrakat berada pada posisi kohesif bukan terbagi. Keempat, kehidupan sosial tergantung pada soliodaritas dan tidak melahirkan pertentangan atau oposisi. Kelima, kehidupan sosial didasarkan pada resioprositas dan kerjasama serta menghindari dan mengeliminasi konflik struktural. Keenam, sistem-sistem sosial bertahan pada konsensus dan tidak melahirkan kepentingan tertentu. Ketujuh, masyarakat mengenal otoritas legitimasi dan didasarkan pada kekuasaan semata. Kedelapan, sistem sosial cenderung untuk bertahan lama dan anti terhadap perubahan. ${ }^{25}$

Parsons juga mengajukan asumsi mengenai struktural fungsional sebagai berikut :

1. Bagian-bagian dari suatu sistem saling ketergantungan dan memiliki sifat yang teratur.

2. Arah dari suatu sistem adalah teratur dan seimbang

3. Proses pergerakan dari suatu sistem bersifat teratur dan agak statis

4. Bagian-bagian dari suatu sistem dipengaruhi oleh bagian yang lain

5. Batas-batas dengan lingkungannya sangat dijaga oleh suatu sistem

24 George Ritzer, Sosiologi Ilmu Pengetabuan Berparadigma Ganda (Jakarta : Rajawali, 1985), h. 25

25 Craib, Teori-teori Sosiologi Moderen dari Parsons sampai Hebermas, (Jakarta, Rajawali Press, 1992), h. 91 
6. Alokasi dan itegrasi merupakan dua proses fundamental yang diperlukan untuk memelihara keseimbangan sistem

7. Sistem cenderung menuju ke arah pemeliharaan keseimbangan diri dan pemeliharaan hubungan antara bagianbagian dengan keseluruhan sistem, mengendalikan lingkungan yang berbeda-beda dan mengendalikan kecenderungan untuk merubah sistem dari luar. ${ }^{26}$

Disini jelaslah bahwa dalam teori struktural fungsional sangat mendambakan keteraturan dan mengabaikan konflik. Jika ada sub sistem tidak dapat bekerja atau menjalankan fungsinya sebagaimana mestinya, maka dengan sendirinya akan hilang dan digantikan oleh yang lain. Penganut teori struktural fungsional sering dituduh mengabaikan variabel konflik dan perubahan sosial dalam masyarakat.

Para penganut teori struktural fungsional menerima perubahan sebagai suatu yang konstan dan tidak memerlukan penjelasan. Perubahan dianggap mengacaukan keseimbangan masyarakat. Proses pengacauan itu berhenti pada saat perubahan tersebut telah diintegrasikan ke dalam kebudayaan. Perubahan yang ternyata bermanfaat (fungsional) diterima dan perubahan lain yang terbukti tidak berguna (disfungsional) ditolak. ${ }^{27}$

Masyarakat dipandang sebagai suatu sistem, dimana masingmasing sub sistem yang saling ketergantungan dan mempunyai fungsi masing-masing. Teori ini memandang kemiskinan sebagai akibat ketidakfungsian ekonomi. Perkembangan industrialisasi telah menghancurkan sistem ekonomi. Kemiskinan disebabkan oleh sistem, dimana ada pihak yang diuntungkan dan ada pihak yang dirugikan.

Penganut teori struktural fungsional memandang segala pranata sosial yang ada dalam masyarakat serba fungsional dalam arti positif dan negatif, termasuk juga kemiskinan. Gans mengemukakan

${ }^{26}$ Geoege Ritzer dan Douglas J. Goodman, Teori Sosiologi Modern, Jakarta : Kencana, 2007), h. 123

27 Paul B. Harton, Sosiologi Edisi keenam, (Jakarta : Erlangga, 1984), h. 
lima belas fungsi kemiskinan yang dapat diredusir menjadi empat kriteria yaitu fungsi ekonomi, sosial, kultural dan politik. ${ }^{28}$

Fungsi ekonomi meliputi :

1. Pekerjaan kotor selalu disediakan oleh masyarakat miskin dalam setiap struktur masyarakat

2. Menimbulkan dana-dana sosial

3. Orang miskin menghendaki lapangan kerja yang baru sehingga pelu dibuka untuk menyalurkan pekerjaan tersebut kepada mereka

4. Orang kaya yang tidak memelukan barang bekas, kemudian dimanfaatkan oloeh orang miskin

5. Kemiskinan menguatkan norma-norma sosial utama dalam masyarakat

6. Menimbulkan altruisme terutama terhadap orrang-orang miskin yang sangat memerlukan santunan

7. Keadaan masyarakat miskin bisa dirasakan oleh orang kaya tanpa mereka harus mengalami kemiskinan itu, tetapi cukup dengan membayangkan dan merasakannya saja

8. Tolak ukur kemajuan kelompok lain, yang dalam hal ini orang kaya

9. Membantu kelompok lain yang sedang berusaha sebagai anak tangganya

10. Munculnya lembaga sosial sebagai wadah bagi orang kaya untuk menyalurkan bntuannya kepada orang miskinl

Fungsi kultural kemiskinan adalah :

1. Monumen-monumen kebudayaan yang dibangun sangat memerlukan tenaga orang miskin karena hanya mereka yang bisa menyediakannya

2. Tidak selamanya budaya orang miskin diabaikan, karena kadang-kadang mereka pun dapat diterima oleh orang yang mempunyai kedudukan lebih tinggi

${ }^{28}$ George Ritzer, Sosiologi Ilmu Pengetabuan ..., h. 27 
Fungsi politik dari kemiskinan adalah :

1. Tidak selamanya orang miskin itu selalu menguntungkan, tetapi kadang-kadang mereka merupkan ancaman bagi kelompok politik tertentu

2. Orang miskin selalu dianggap sebagai kelompok yang selalu harus dibantu dalam proses perubahan dan pertumbuhan masyarakat.

3. Kemiskinan menyebabkan sistem politik lebih centrist dan lebih stabil alasan :

Kemiskinan akan tetap berlangsung (menurut Gans) dengan

1. Kelompok-kelompok dalam masyarakat masih menganggap bahwa kemiskinan masih ada manfaatnya

2. Fungsi orang miskin sampai saat ini belum ada pilihan yang lain

3. Alternatif yang ada masih saja lebih mahal dari pada imbalan kesenangan yang diberikannya. ${ }^{29}$

Demikianlah fungsi kemiskinan yang dikemukakan oleh Gans, yang bukan berarti bahwa kemiskinan itu perlu dan tidak bisa dihilangkan atau paling tidak diminimalisir. Diperlukan upaya-upaya untuk mengatasi kemiskinan yang terjadi di masyarakat. Kemiskinan akan lenyap jika kemiskinan sudah tidak berfungsi lagi bagi kemakmuran dan juga bila orang miskin berusaha sekuat tenaga untuk mengubah sistem yang dominan dalam stratifikasi sosial. Jika pekerjaan yang seharusnya dikerjakan oleh orang miskin sudah digantikan oleh tenaga mesin dan keadaan masyarakat sudah semakin membaik dan merata maka keadaan dalam masyarakat akan tetap stabil walaupun tidak ada kemiskinan.

\section{E. Penutup}

Kemiskinan selalu hadir dalam setiap masyarakat, baik itu masyarakat moderen (masyarakat perkotaan), terlebih lagi pada

${ }^{29}$ Ibid, h.29 
masyarakat yang masih sederhana (masyarakat pedesaan). Upaya pengentasan kemiskinan pun sudah dilakukan dengan berbagai cara, baik itu menggunakan pendekatan top-down maupun bottom-up, walaupun hasilnya masih jauh dari harapan, tetapi kita harus tetap berupaya agar kemiskinan dapat segera dikurangi. Perlu adanya kerja sama antara pemerintah dan masyarakat agar kemiskinan itu dapat diminimlisir. 


\section{Daftar Pustaka}

Abdulsyani, Sosiologi Skematika Teori dan Terapan, Jakarta : Bumi Aksara, 1994

Craib, Teori-Teori Sosiologi Moderen dari Parsons sampai Hebermas, Jakarta : Rajawali Press, 1992

Effendi, Noer Tadjuddin, Sumber Daya Manusia, Peluang Kerja, dan Kemiskinan, Yogyakarta : Tiara Wacana, 1995

Jamaluddin, Adon Nasrullah, Sosiologi Perkotaan Memahami masyarakat Kota dan Problematikanya, Bandung: Pustaka Setia, 2015

Raho, Bernard, Teori Sosiologi Moderen, Jakarta : Prestasi Pustaka, 2007

Ritzer, George, Sosiologi Ilmu Pengetahuan Berparadigma Ganda, Penyadur Alimandan, Jakarta : Rajawali Douglas J, 1995

Ritzer, George dan. Goodman, Teori Sosiologi Modern, Jakarta : Kencana, 2007

Rohmad, Zaini, Sosiologi Pembangunan, Yogyakarta : Ombak Tiga, 2016

Sanderson, Stephen K, Sosiologi Makro, Jakarta : Rajawali Press, 1993

Soekanto, Soerjono, Sosiologi Suatu Pengantar, Jakarta : Raja Grafindo Persada, 1994

Sulistiyani, Ambar Teguh, Kemitraan dan Model-model Pemberdayaan, Yogyakarta: Gsava Media, 2004

Sumodiningrat, Gunawan dan Wulandari, Ari, Membangun Indonesia dari Desa sebagai Kunci Kesuksesan Pembangunan Ekonomi Untuk Meningkatkan Kesejabteraan Rakyat, Yogyakarta : Media Pressindo, 2016

Suparlan, Parsudi, Kemiskinan di Perkotaan, Jakarta : Yayasan Obor Indonesia, 1995

Wahidi D, Roestanto, Membangun Perdesaan Moderen Tata Kelola Infrastruktur Desa, Bogor : Indodata Development Center, 2015

Wargadinata, Wildan, Islam dan Pengentasan Kemiskinan, Malang : UIN Maliki Press, 2011 